\title{
活動報告
}

\section{どうやって医学生に地域医療を教育するか？ 一地域医療体験キャンプを通じた地域医療教育の実践—}

Educating medical students in rural area through a rural medicine experience camp

\section{若 林 崇 雄* 武田真一 藤戸善伸 山本 和 利}

Takao Wakabayashi Shinichi Takeda Yoshinobu Fujito Wari Yamamoto

\begin{abstract}
要 旨
札幌医科大学では地域枠の学生を対象に地域医療体験キャンプを行っている.この際, 事前にすでに地域医療 を経験した先輩による地域医療についての講義とキャンプ参加者自身によるキャンプ前の学習内容設定が地域 枠学生の地域医療への動機を維持・向上するかどうかを検討した。学生は, 前者により地域医療に対する理解 を深め, 後者によって地域医療に対する様々な課題を発見する事が示唆された. 我々は地域医療教育に様々な 方法を試行し，地域医療に対する学生の動機を確保することが重要と考えた.
\end{abstract}

\begin{abstract}
A rural medicine experience camp is held every year for medical students of Sapporo Medical University who are obligated to work in rural area after graduation. We organized two method in our camp : 1. the lecture about rural medicine by senior medical students, 2 . setting up the learning content in camp by participant before camp. We investigated how these methods make an impact on the participant's motivation about rural medicine. The results suggested that a method 1 enhanced the understanding of rural medicine and method 2 raised an a warenss about rural medicine. We thought that it was important to try various education about rural medicine for increasing the motivation to rural medicine for medical student.
\end{abstract}

Keywords : 地域医療, キャンプ, 高学年による講義, 事前の学習項目設定, 医学教育

\section{目 的}

医師の地理的偏在は多くの国で社会問題となってい る. 日本では 1980 年代以降, へき地と都市部の格差 は縮小しておらず1), 英国と比較して 2 倍程度都市部 へ偏在しているという報告もある2).

このため日本では各大学が 2007 年以降, 卒後一定 期間の地域医療を義務とする地域枠を設置するように なった. したがって地域医療への動機向上につながる 卒前教育の重要性が増しているが, その具体的な内容 や方法については報告が少ない.

筆者が勤務する札幌医科大学でもこれに関し試行錯 誤しているが, 本稿ではその中で学生から好評だった 地域医療体験キャンプについて報告を行いたい。

\section{方 法}

札幌医科大学では 2008 年よりいわゆる地域枠（特
別推薦枠制度）が設定されている。これは北海道が主 導し，授業料などがすべて免除される代わりに卒業 後, 北海道内での医療を 9 年間 (うち地域医療 5 年間) 義務づけられる制度であり，2013 年現在，卒業後に 何らかの義務を負う学生が 64 名在籍している.

札幌医科大学では, 地域医療を志す学生団体（以下 FLAT : frontier local activity team と記す）を組織 し学習会を重ねてきた。この活動の一環として年に 1 度, 低学年を中心に地域医療体験キャンプを実施して きた。

2013 年度も我々は北海道の留寿都村（人口 1872 名, 人口密度 15.6 名 $/ \mathrm{km}^{2} 2014$ 年 3 月末）でキャン プを計画した.

まずキャンプ前にすでに学内の地域包括実習やクリ ニカル・クラークシップ, また自主的な見学を通じ地 域医療を経験した 6 年生が低学年に地域医療に関する

*著者連絡先 : 札幌医科大学地域医療総合医学講座 [ $\overline{\mathrm{T}} 060-8543$ 札幌市中央区南 1 条西 16 丁目] email : takawakaba@sapmed.ac.jp

（受付日：2014 年 11 月 14 日，採用日：2015 年 3 月 16 日） 


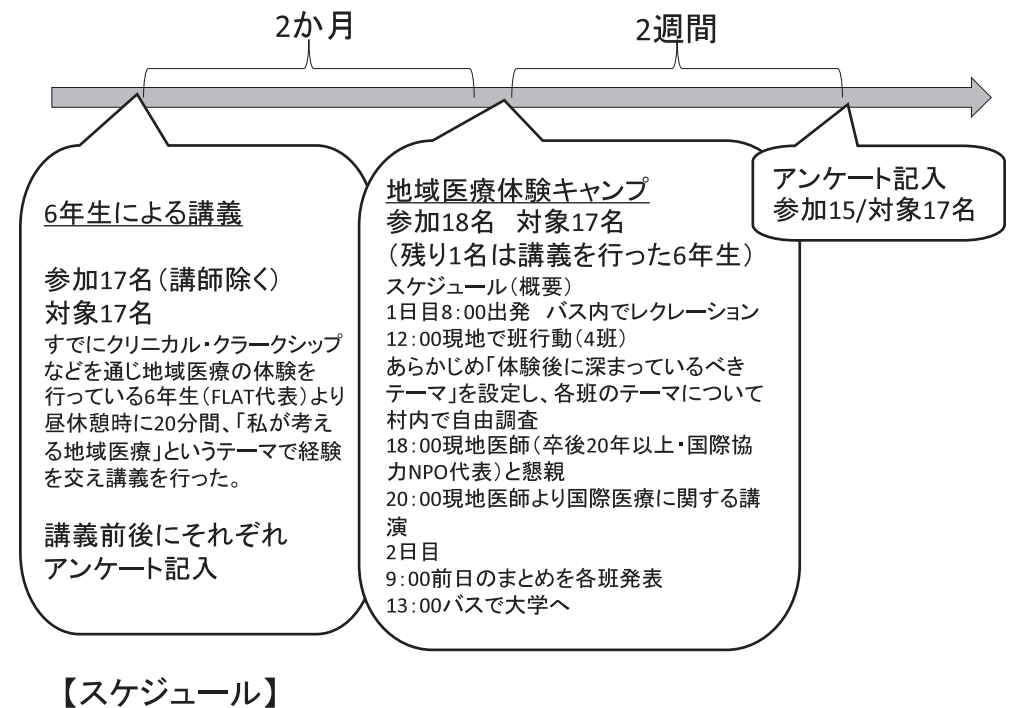

図 1

体験を語る講義の場を設け, ある程度地域医療への予 備知識を得ることとした（後述(1)に関連). その 2 か 月後に地域医療体験キャンプを行った. 1 泊 2 日で初 日は 4 班に分かれてあらかじめ「キャンプ終了後に深 まっているべき地域医療に関する知識」を班ごとに議 論の上設定し, 現地で調査を行った(後述(2)に関連). 現地の医師との夕食後に医師より国際医療に関するレ クチャーを受けた。 2 日目は前日の調査をまとめ, 留 寿都の地域医療に関する発表を行った（図 1).

(1)学生による地域医療の講義は臨床における屋根瓦 方式 ${ }^{3)}$ (直近の先輩医師が後輩医師を指導すること) を参考に実施した。これは教員の講義が学生の地域医 療への動機を向上しにくく, 我々教員がその教育効果 に限界を感じていたため実施した。講義終了前後でア ンケートを取った.

質問内容

\section{講義前/講義後（同じ設問）}

1, あなたは現在, 北海道の人口の少ない地域で一定 期間医療を行うことに意欲がありますか?

$$
\text { 全くない } 1234 \text { とてもある }
$$

2 , 現在考える地域医療について自由に記載してくだ さい

(2)実地調査であらかじめ「キャンプ終了後に深まっ ているべき知識」を班ごとに議論の上設定する試みは Chan ${ }^{4)}$ らよる学習契約を参考とした。学習契約とは 学習前に学習後, 深まっている知識をあらかじめ設定 (契約) することであり，医療における成人学習 ${ }^{4) 5}$ に
有効性が報告されている. 我々のキャンプではこれを 大幅に簡略化し, 班ごとにキャンプ後深まっているべ き知識を設定した。キャンプ前後でアンケートを取 り，振り返りの代わりとした。

\section{質問内容}

\section{キャンプ後}

1，あなたは現在，北海道の人口の少ない地域で一定 期間医療を行うことに意欲がありますか?

$$
\text { 全くない } 1120 \quad 3 \quad 4 \quad 5 \text { とてもある }
$$

2, キャンプにおいてテーマを設定することに意義を 感じましたか？

全く感じなかった $1142 \quad 3 \quad 4 \quad 5$ とて も感じた

3，キャンプ前に講義を受けた方にお尋ねします。 キャンプ前に講義を受けることに意義を感じまし たか?

受けていない＼cjkstart全く感じなかった 112434 5 とても感じた

4, 現在考える地域医療について自由に記載してくだ さい.

統計解析には Excel2010を使用した。

なお，札棍医科大学地域医療総合医学講座が地域医 療への early exposure を兼ねて低学年を中心にキャ ンプへの参加を呼び掛けるため, FLATの学生の多 くは在学中に 1 回以上キャンプに参加するが, その参 加は正規の単位などが関わるものではなく強制される ものではない。キャンプの対象は全学年であるが臨床 実習が始まる前の低学年での参加が例年多い。キャン 
プ参加希望者には 6 年生の講義に参加するよう呼びか けたが,これも必須とはしていない. (1)(2)の調査に関 してはキャンプ参加を FLAT のメーリングリストで 呼びかけ自主的に参加を希望した学生に対し文書によ り同意を得た。

\section{結 果}

キャンプへの参加者は 18 名だった.このうち講義 を行った 6 年生を除く 17 名を検討の対象とした. 参 加者全員から検討に参加する同意を得た。(1)の検討で はキャンプ参加者全員が参加し, 17 名だった. 内訳
は 1 年生 12 名, 3 年生 4 名, 6 年生 1 名. 講義前の地 域医療への意欲を示す平均值（1：ない -5 ：あるまで の 5 段階の Likert scale で評価) は $4.18 \pm 0.81$ (Mean $\pm \mathrm{SD}$, 以下同じ), 講義後は $4.41 \pm 0.80$ であり, 僅 差ながら講義前後において地域医療への意欲は有意に 上昇した $(\mathrm{p}<0.05)$.

(2)の検討ではキャンプに参加した 17 名のうち 15 名 が参加した. 内訳は不明. キャンプ後の地域医療への 意欲を示すスケールの平均点は $4.27 \pm 0.59$ （講義前 との比較 $\mathrm{p}=0.25$, 講義後との比較 $\mathrm{p}=0.28 ）$ と高 く, 講義前後と比較して有意差は認めなかった.

表 1

講義前

\begin{tabular}{|c|c|}
\hline & アンケート例（原文のまま） \\
\hline \multicolumn{2}{|l|}{$\begin{array}{l}\text { テーマ(1) } \\
\text { 医師にかかる大きな負担 }\end{array}$} \\
\hline 医師が少ない & $\begin{array}{l}\text { 都市部に医師が偏在 } \\
\text { 医師数が非常に少なく，地域で医師は精いっぱい努力しているが間に合っていない など }\end{array}$ \\
\hline 情報が少ない & 情報格差が医療従事者の格差解消と未だリンクしていない \\
\hline 検査ができない & 必要な検査ができない など \\
\hline 自主性が求められる & 自主性が求められる など \\
\hline 総合性が必要である & 全部みれるのが必要 専門以外の範囲の知識 など \\
\hline \multicolumn{2}{|l|}{$\begin{array}{l}\text { テーマ(2) } \\
\text { 不明確な地域医療 }\end{array}$} \\
\hline 地域ならではの特性 & 地域ならではの特性 など \\
\hline \begin{tabular}{|l} 
地域医療に対する漠然と \\
したイメージ
\end{tabular} & $\begin{array}{l}\text { 漠然としすぎてイメージできない 実態をあまり理解していない 地域医療という言葉が先行 な } \\
\text { ど }\end{array}$ \\
\hline \multicolumn{2}{|l|}{\begin{tabular}{|l} 
テーマ(3) \\
地域医療に関する要望
\end{tabular}} \\
\hline 皆で分かち合う地域医療 & 一部の人が大きな負担を負うのではなく皆で少しずつ負担できる体制 \\
\hline 医師派遣のシステム & 大学や行政としては仕組みとして効率よく, かつ持続可能な仕組み 都市から派遣 など \\
\hline 設備投資 & 専門医を増やしていくための設備投資 \\
\hline
\end{tabular}

\section{講義後}

\begin{tabular}{|l|l|}
\hline & Pンケート例 \\
\hline $\begin{array}{l}\text { テーマ } \\
\text { 地域医療への理解 }\end{array}$ & $\begin{array}{l}\text { 若干のマイナスのイメージを持っていましたが, さまざまなプラス面があることを知りました } \\
\text { マイナスイメージは地域に根ざしているからこそできる治療があるといったプラスのものになった } \\
\text { など }\end{array}$ \\
\hline $\begin{array}{l}\text { なメージの転換 } \\
\text { 患者と関わりが深い }\end{array}$ & $\begin{array}{l}\text { 患者さんとの距離がきわめて近い医療である 医師と患者との関係以前に, 人として患者とつき } \\
\text { あっていく医療 など }\end{array}$ \\
\hline 地域と関わりが深い & $\begin{array}{l}\text { 地域との関わりが密で温かなつながり 診療するだけでなく, 地域の人々との関係を築いていくこ } \\
\text { とが大切 }\end{array}$ \\
\hline ジェネラリストが有用 & $\begin{array}{l}\text { 地域では (中略) 幅広い知識が求められる 総合医といっても家庭医と総合診療医がいる 専門外 } \\
\text { だから診られないと医師になりたくない など }\end{array}$ \\
\hline 家族との時間が持てる & 家族と一緒に過ごせる時間が多い 家族といる時間が長いのはすごく地域医療の特徵 \\
\hline
\end{tabular}




\begin{tabular}{|c|c|}
\hline $\begin{array}{l}\text { テーマ(2) } \\
\text { 地域医療に対する能動的 } \\
\text { な意思 }\end{array}$ & \\
\hline 働き方への共感 & $\begin{array}{l}\text { 親が地域医療に携わっていたので, その時のことを聞いたのと似ているな } \\
\text { おこしに病院の外に出たい, 町 } \\
\end{array}$ \\
\hline 特別ではない地域医療 & $\begin{array}{l}\text { へき地, 都市に限らず人とのつながりを重んじる地域医療 特別と考えられがちだが, 地域が普通 } \\
\text { となるべき }\end{array}$ \\
\hline $\begin{array}{l}\text { テーマ(3) } \\
\text { 地域医療への新たな動機 }\end{array}$ & \\
\hline 地域医療へ従事したい & 病院の中だけでなく, 地域社会で仕事をできる医師になりたい＼cjkstart私も家庭医になりたい \\
\hline $\begin{array}{l}\text { さらに地域医療を学びた } \\
\text { い }\end{array}$ & $\begin{array}{l}\text { キャンプなどを通じて, 地域医療について学んでいきたい 漁村での地域医療をもっともっと学び } \\
\text { たい 夏休みなどを利用してぜひ自も行ってみよう }\end{array}$ \\
\hline
\end{tabular}

\begin{tabular}{|c|c|}
\hline & アンケート例 \\
\hline \multicolumn{2}{|l|}{$\begin{array}{l}\text { テーマ(1) } \\
\text { 知らなかった地域医療 }\end{array}$} \\
\hline 未経験だった & 何も知らず, 行ったこともない状態では, 何も想像できず, ポジティブな印象を持っていなかった \\
\hline 自己犠牲のイメージ & 少ない医師がみんなの健康を支えている, やや自己犠牲的な側面 \\
\hline \multicolumn{2}{|l|}{\begin{tabular}{l|} 
テーマ(2) \\
体験を通じたイメージ形 \\
成と自己の変化
\end{tabular}} \\
\hline 現地を通して知る地域医 & $\begin{array}{l}\text { やりがいや働き方について自分なりの感触 思っていたほど悲惨ではない 暇もかなりある 自分 } \\
\text { らしい生活 など }\end{array}$ \\
\hline $\begin{array}{l}\text { 地域医療のイメージの多 } \\
\text { 様化 }\end{array}$ & $\begin{array}{l}\text { 様々なニーズ 様々な形 様々なタイプ } \bigcirc \text { (キャンプ地) のような地域医療もあれば, } \times \times(\text { 過 } \\
\text { 疎地区基幹病院) のような地域の中核病院のタイプのような地域医療もある 变えることが必要な } \\
\text { こともあれば, 現状がすでに渪足できるものである地域がある など }\end{array}$ \\
\hline 地域医療への動機向上 & $\begin{array}{l}\text { モチベーションが上がった より地域医療に携わりたい気持ち 地域医療をやるかどうかよりも, } \\
\text { 地域でどのような医療をやるかに関心 求められている医療を（中略）自分で確かめて, 将来にい } \\
\text { かしていきたい など }\end{array}$ \\
\hline \multicolumn{2}{|l|}{$\begin{array}{l}\text { テーマ(3) } \\
\text { キャンプ後得た課題 }\end{array}$} \\
\hline 内部的課題を発見 & $\begin{array}{l}\text { 技術不足で患者さんに迷惑をかけても申し訳ない 地域を知り, 密着した医療を行うことが大切 } \\
\text { コミュニケーション 年寄りともっと上手にコミュニケーションをとれるようになりたい 信頼関 } \\
\text { 係を築くことも大事 } \\
\text { など }\end{array}$ \\
\hline 外部的課題を発見 & 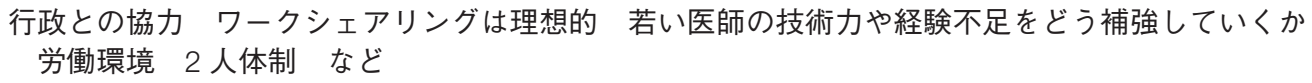 \\
\hline
\end{tabular}

また全体を通して (1), (2)に対し平均 4.07 と比較的 高く意義を感じていた．このことは講義前後やキャン プ後の学生の自由記載の感想 (表 1) にも表れていた.

講義前, 学生はイメージが先行しており実態をよく 知らなかったが, 講義後, 学生の地域医療へのイメー ジは患者と距離が近い，地域との関わりが密である， 家族と過ごせる時間が多いなど具体的で多彩に変化し た。 また地域では幅広い知識が求められ, それには総 合診療を実践することが有効という気づきがあった。 イメージの変化は地域の一員となる能動的な意思へ変 化し, 地域医療について学びたい, 従事したいという 動機へつながっていた.
キャンプ前, 学生は地域医療に自己犠牲的なイメー ジを持っていたが, キャンプ後, 自分らしい生活をも つことができることを理解し地域医療に余裕があると ころ・多忙なところと様々な形があることを認識して いた．地域医療実践の動機が向上し，コミュニケー ションや信頼関係を築くことなど個人的な課題と, 行 政との協力・労働環境整備・予防医学など社会的な課 題を発見していたことが示唆された.

\section{考 察}

現在, 医学教育において地域の中で教育することの 重要性が指摘されている ${ }^{6}$. 本キャンプは志を同じく 
する様々な学年の学生と交流し，地域医療を実践する 医師と懇親するなど楽しみながら地域医療の実態を学 ぼうという趣旨にそって実施している。筆者は教員と してキャンプに付き添ったが，大学での学習では見ら れない学生の活き活きとした笑顔がとても印象的だっ た。

今後, 本キャンプは幌加内町立国保病院が中心と なって旭川医科大学の学生なども交えながら発展して いくことが決定している。近年，WHO はへき地に扔 ける政策ガイドライン ${ }^{7)}$ の中で医師偏在を修正するた めに，医学生を様々な地域医療へ暴露する医学教育へ の介入が不可欠と指摘して㧍り, 我々は今後も今回の キャンプのように地域での実践を通じた効果的な地域 医療教育を模索していく必要があると考えた。

本論文に関連する利益相反はありません。

\section{文 献}

1) Inoue $K$, Matsumoto $M$, Toyokawa $S$ et al : Transition of physician distribution (1980-2002) in Japan and factors predicting future rural practice. Rural and remote health. $2009 ; 9: 1070$.

2) Matsumoto $M$, Inoue $K$, Farmer J et al : Geographic distribution of primary care physicians in Japan and Britain. Health and Place. $2010 ; 16: 164-166$.

3）錦織宏，鈴木富雄，三島信彦ほか：臨床研修の充実家 による地域の医師確保モデルの提唱（その1). 医学 教育. 2009. 40 : 19-25.

4) Chan SW, Chien WT : Implementing contract learning in a clinical context : report on a study. Journal of Advanced Nursing. $2000 ; 31: 298-305$.

5) Ramli A, Joseph L, Lee SW : Learning pathways during clinical placement of physiotherapy students : a Malaysian experience of using learning contracts and reflective diaries. Journal of Educational Evaluation for Health Professions. $2013 ; 10: 6$.

6) Worley P, Silagy C, Prideaux D et al : The Parallel Rural Community Curriculum : an integrated clinical curriculum based in rural general practice. Medical Education. $2000 ; 34: 558-565$.

7) World Health Organization : Increasing access to health workers in remote and rural areas though improved retention: global policy recommendation. Geneva : WHO/2010/URL : http://whqlibdoc.who. int/publications/2010/9789241564014_eng.pdf 